Correspondence Maiken Cavling Arendrup mad@ssi.dk
Received 2 November 2009 Accepted 30 December 2009

\section{Molecular screening for Candida orthopsilosis and Candida metapsilosis among Danish Candida parapsilosis group blood culture isolates: proposal of a new RFLP profile for differentiation}

\author{
Hossein Mirhendi, ${ }^{1,2}$ Brita Bruun, ${ }^{3}$ Henrik Carl Schønheyder, ${ }^{4}$ \\ Jens Jørgen Christensen, ${ }^{5}$ Kurt Fuursted, ${ }^{6}$ Bente Gahrn-Hansen, ${ }^{7}$ \\ Helle Krogh Johansen, ${ }^{8}$ Lene Nielsen, ${ }^{9}$ Jenny Dahl Knudsen ${ }^{10}$ \\ and Maiken Cavling Arendrup ${ }^{2}$
}

\footnotetext{
${ }^{1}$ Department of Medical Mycology and Parasitology, Faculty of Public Health and National Institute of Health Research, Tehran University of Medical Sciences, Tehran, Iran

${ }^{2}$ Mycology and Parasitology Unit, Statens Serum Institut, Copenhagen, Denmark

${ }^{3}$ Department of Clinical Microbiology, Hillerød Hospital, Hillerød, Denmark

${ }^{4}$ Department of Clinical Microbiology, Aalborg Hospital, Aarhus University Hospital, Aalborg, Denmark

${ }^{5}$ Clinical Microbiology Unit, Statens Serum Institut, Copenhagen, Denmark

${ }^{6}$ Department of Clinical Microbiology, Skejby Hospital, Aarhus University Hospital, Aarhus, Denmark

${ }^{7}$ Department of Clinical Microbiology, Odense University Hospital, Odense, Denmark

${ }^{8}$ Department of Clinical Microbiology, Rigshospitalet, Copenhagen University Hospital, Copenhagen, Denmark

${ }^{9}$ Department of Clinical Microbiology, Herlev University Hospital, Herlev, Denmark

${ }^{10}$ Department of Clinical Microbiology, Hvidovre University Hospital, Hvidovre, Denmark
}

\begin{abstract}
Candida orthopsilosis and Candida metapsilosis are recently described species phenotypically indistinguishable from Candida parapsilosis. We evaluated phenotyping and molecular methods for the detection of these species among 79 unique blood culture isolates of the C. parapsilosis group obtained during the years 2004-2008. The isolates were screened by PCR amplification of the secondary alcohol dehydrogenase-encoding gene $(S A D H)$ followed by digestion with the restriction enzyme Banl, using C. parapsilosis ATCC 22019, C. orthopsilosis ATCC 96139 and C. metapsilosis ATCC 96144 as controls. Isolates with RFLP patterns distinct from C. parapsilosis were characterized by sequence analysis of the ITS1-ITS2, 26S rRNA (D1/D2) and $S A D H$ regions. Restriction patterns for the 3 species with each of 610 restriction enzymes were predicted in silico using 12 available sequences. By PCR-RFLP of the SADH gene alone, four isolates $(5.1 \%)$ had a pattern identical to the C. orthopsilosis reference strain. Sequence analysis of SADH and ITS (internal transcribed spacer) regions identified two of these isolates as $C$. metapsilosis. These results were confirmed by creating a phylogenetic tree based on concatenated sequences of $S A D H$, ITS and 26S rRNA gene sequence regions. Optimal differentiation between C. parapsilosis, C. metapsilosis and C. orthopsilosis was predicted using digestion with Nlalll, producing discriminatory band sizes of: 131 and 505 bp; 74, 288 and 348 bp; and 131, 217 and $288 \mathrm{bp}$, respectively. This was confirmed using the reference strains and 79 clinical isolates. In conclusion, reliable discrimination was obtained by PCR-RFLP profile analysis of the SADH gene after digestion with Nlall but not with Banl. C. metapsilosis and C. orthopsilosis are involved in a small but significant number of invasive infections in Denmark.
\end{abstract}




\section{INTRODUCTION}

Candida parapsilosis is one of the five most common yeasts involved in invasive candidiasis and is particularly common in neonates, in catheter-associated candidaemia and in association with intravenous hyperalimentation (Krcmery \& Barnes, 2002). In Denmark, it is involved in $4 \%$ of the fungaemia cases (Arendrup et al., 2008). C. parapsilosis is normally susceptible to most antifungal compounds but elevated MICs for the echinocandin agents are consistently reported for this species due to an intrinsic mutation in the FKS hot spot (Garcia-Effron et al., 2008). Susceptibility differences within the $C$. parapsilosis group could affect therapeutic choices (van Asbeck et al., 2008).

C. parapsilosis is a complex of three genetic groups (I, II and III) according to the results from genotypic methods, including randomly amplified polymorphic DNA (RAPD) analysis (Lehmann et al., 1992), karyotyping (Lott et al., 1993), multilocus enzyme electrophoresis, ribosomal internal transcribed spacer (ITS) sequencing (Lin et al., 1995), DNA reassociation analysis (Roy \& Meyer, 1998), DNA topoisomerase II gene sequencing (Kato et al., 2001), complex DNA probe pattern analysis by Southern blotting (Enger et al., 2001) and mitochondrial DNA sequence differences (Nosek et al., 2002). In 2005 Tavanti et al. (2005) reported a multilocus sequence typing scheme and suggested C. parapsilosis groups II and III should be reclassified as the species Candida orthopsilosis and Candida metapsilosis, respectively. C. parapsilosis was retained for group I. PCR amplification of the secondary alcohol dehydrogenaseencoding gene $(S A D H)$ followed by digestion of the PCR product with the restriction enzyme BanI was proposed for differentiation of these three new species. Subsequently, some retrospective epidemiological studies have been undertaken to screen for C. orthopsilosis and C. metapsilosis among previously identified $C$. parapsilosis isolates showing that a small proportion of such blood culture isolates are actually C. orthopsilosis or C. metapsilosis, with a significant geographical variation (Asadzadeh et al., 2009; GomezLopez et al., 2008; Gonçalves et al., 2010; Kocsubé et al., 2007; Lockhart et al., 2008; Pryce et al., 2006; Silva et al., 2009; Tavanti et al., 2005, 2007; Tay et al., 2009).

In the present study, Candida isolates identified as $C$. parapsilosis group by conventional phenotyping methods during an ongoing population-based surveillance of candidaemia (Arendrup et al., 2008) were genotypically screened for $C$. orthopsilosis and C. metapsilosis. Sequence analysis of selected gene targets suggested that PCR-restriction fragment length polymorphism (RFLP) of the SADH gene by BanI is not sufficient for differentiating the three closely related species in the C. parapsilosis group, and therefore, an alternative RFLP profile algorithm is proposed for reliable identification.

\section{METHODS}

Isolates. A total of 79 clinical C. parapsilosis group isolates and 3 reference strains, C. parapsilosis ATCC 22019, C. orthopsilosis ATCC
96139 and C. metapsilosis ATCC 96144, were used in this study. Clinical strains were obtained from Danish patients with candidaemia during 2004-2008 (Arendrup et al., 2008). Species identification was based on colony colour and morphology on CHROMagar, microscopic morphology on cornmeal agar and use of a commercial system (ATB ID32C). The isolates had been stored in glycerol/water at $-80{ }^{\circ} \mathrm{C}$. All strains were subcultured on CHROMagar and incubated at $37^{\circ} \mathrm{C}$ for $48 \mathrm{~h}$ for reconfirmation of the identification as $C$. parapsilosis sensu lato. Susceptibility testing was performed according to the European Committee on Antimicrobial Susceptibility Testing Edef 7.1 guidelines (AFST-EUCAST, 2008).

PCR. Reference and clinical strains were subjected to amplification of the $S A D H$ gene. A small part (about $0.5-1 \mu \mathrm{l}$ ) of a single fresh colony was added directly, and without prior DNA extraction (Mirhendi et al., 2007) to the PCR premix, which contained $0.5 \mu \mathrm{M}$ of the forward (5'-GTT GAT GCT GTT GGA TTG T- $3^{\prime}$ ) and reverse (5'-CAA TGC CAA ATC TCC CAA-3') primers (Tavanti et al., 2005), $400 \mu \mathrm{M}$ deoxynucleoside triphosphate mix, $2.5 \mu \mathrm{l}$ magnesium-free buffer, $1.5 \mathrm{mM} \mathrm{MgCl}_{2}$ and 1.25 U Taq DNA polymerase (Sigma-Aldrich) in a final volume of $25 \mu \mathrm{l}$. A negative control (water) was included in all PCR experiments. Conditions for PCR amplification were: $94{ }^{\circ} \mathrm{C}$ for $7 \mathrm{~min} ; 35$ cycles of denaturation at $95{ }^{\circ} \mathrm{C}$ for $30 \mathrm{~s}$, annealing at $55^{\circ} \mathrm{C}$ for $60 \mathrm{~s}$ and elongation at $72{ }^{\circ} \mathrm{C}$ for $90 \mathrm{~s}$; and a final extension step at $72{ }^{\circ} \mathrm{C}$ for $5 \mathrm{~min}$.

RFLP. The SADH PCR products were digested for 120 min with the restriction enzyme BanI or NlaIII (Fermentas), in a $15 \mu \mathrm{l}$ reaction volume containing $0.5 \mu \mathrm{l}(5 \mathrm{U})$ enzyme, $1.5 \mu \mathrm{l} 10 \times$ buffer (supplied with the enzyme), $5 \mu \mathrm{l}$ PCR product and $8 \mu$ l molecular grade water.

Electrophoresis. A total of $5 \mu \mathrm{l}$ amplified DNA and $8 \mu$ ldigested DNA product were separated by electrophoresis on 1.5 and $2 \%$ agarose gels, respectively. The electrophoresis buffer was TBE $(90 \mathrm{mM}$ Tris, $90 \mathrm{mM}$ boric acid, 2 mM EDTA, pH 8.3). A 100 bp DNA ladder was used as a molecular size marker. DNA bands were visualized by UV transillumination and photographed.

Sequencing. The following forward and reverse primer pairs were used for amplification and sequencing of the target DNA regions: $5^{\prime}$ TCC GTA GGT GAA CCT GCG G-3' and 5-TCC TCC GCT TAT TGA TAT GC-3' for the ITS1 $-5.8 \mathrm{~S}$ rRNA gene-ITS2 region (White et al., 1990); 5'-GCA TAT CAA TAA GCG GAG GAA AAG-3 and 5' GGT CCG TGT TTC AAG ACG-3' for the D1/D2 domain of the large subunit of rDNA gene (26S rDNA) (Fell, 1993); and 5'-GTT GAT GCT GTT GGA TTG T- ${ }^{\prime}$ and $5^{\prime}$-CAA TGC CAA ATC TCC CAA- ${ }^{\prime}$ for the SADH gene (Tavanti et al., 2005). Sequencing was performed in all cases by the company MWG using a BigDye terminator cycle sequencing kit and an ABI-3730 genetic analyzer.

Sequence analysis. Forward and reverse sequences were aligned and compared to ensure agreement, and then subjected to nucleotide BLAST search (http://blast.ncbi.nlm.nih.gov/Blast.cgi) and DNASIS multiple alignment. Four separate phylogenetic analyses of sequence data were conducted: three using each individual SADH, ITS1-ITS2 and $26 \mathrm{~S}$ rRNA gene sequence data for sequences determined in the present study and employing the same Candida dubliniensis data for the outgroup; and one using concatenated SADH + ITS1-ITS2 + 26S rRNA data representing the total nucleotide variation in all three regions of the tested strains, with $C$. dubliniensis as the outgroup. The analyses were run using the Bayesian inference method with the program MrBayes v.3.1.2. The evolutionary distance was calculated by employing the general time reversible evolutionary model $($ nset $=6)$, which utilizes a gamma-shaped variation in mutation rates between codons $($ rates $=$ gamma). Posterior probabilities were calculated via 2000000 generations $($ ngen $=2000000$, burnin $=20000)$ using the Monte Carlo 
Markov chain method and four simultaneous tree building chains (nchains $=4)$, with every 100th tree saved (samplefreq $=100$ ).

Designing a new RFLP profile. The $S A D H$ sequences obtained in this study (GenBank accession nos FJ746046-FJ746069) and all available $S A D H$ sequences deposited in GenBank for isolates belonging to the C. parapsilosis group (http://www.ncbi.nlm.nih. gov/) were compared and analysed by DNASIs software. The cutting sites of enzymes listed in the DNASIS software were predicted and evaluated for potential to discriminate between C. parapsilosis, C. metapsilosis and C. orthopsilosis.

\section{RESULTS AND DISCUSSION}

The colony colour of the 79 C. parapsilosis sensu lato isolates was white-cream to pale pink on CHROMagar Candida with slight, but not species-specific, differences among the isolates. ITS and the 26S rRNA gene sequence are well-known targets for most of the taxonomic studies in nearly all microorganisms. They are the basis of routine and research identification of fungal pathogens and for recognizing new species (Iwen et al., 2002). The $S A D H$ gene has been the basis of sequencing analysis or BanI-RFLP for identification of the C. parapsilosis group since the new species were described in 2005 by Tavanti and colleagues (Tavanti et al., 2005). Thus these genes were chosen for comparative studies of the isolates. The $S A D H$ gene was successfully amplified in all the clinical isolates, as well as the reference strains, and a single sharp band with a size of approximately $720 \mathrm{bp}$ was seen for all samples. Digestion of PCR products by the restriction enzyme BanI resulted in three different band patterns (Fig. 1). A double band pattern (approx. 520 and $200 \mathrm{bp}$ in size) was observed for 75/79 clinical isolates. A single band representing the absence of a cutting site for BanI was seen for $C$. orthopsilosis ATCC 96139 (Fig. 1, lane 2) and four clinical isolates (Fig. 1, lanes 4, 5, 10 and 21). These results were reproduced three times for these strains in order to exclude any errors in the enzymic reaction. Finally, as expected, a three band pattern (approx. 390, 190 and $100 \mathrm{bp}$ ) was observed for C. metapsilosis ATCC 96144 (Fig. 1, lane 1) (a fourth 40 bp band is not visible by gel electrophoresis). Thus, according to the digestion patterns described previously (Tavanti et al., 2005), 75 blood culture isolates were identified as $C$. parapsilosis, 4 as C. orthopsilosis (strains W36279, T27682, T19754 and F10552), and none as C. metapsilosis (Table 1).

For confirmation of the species identification obtained by SADH-RFLP, each of the three reference strains, the four blood culture isolates identified as C. orthopsilosis by RFLP and three randomly selected $C$. parapsilosis isolates, were sequenced for the three DNA markers: $S A D H$, the entire ITS1-ITS2 region and 26S rRNA (D1/D2) gene sequence. Forward and reverse sequences determined were completely compatible. The sequences were subjected to a nucleotide BLAST search and sequence analysis of the SADH and ITS1ITS2 regions, which resulted in identification of two isolates (strains T27682 and F10552) as C. orthopsilosis (Fig. 1, lanes 5 and 21) and two isolates (strains T19754 and W36279) as C. metapsilosis (Fig. 1, lanes 4 and 10) (Table 1). There was no cutting site for the enzyme BanI at in silico digestion of the sequences of these isolates. For the American Type Culture Collection (ATCC) reference strains and three randomly selected $C$. parapsilosis isolates sequence analysis of the SADH gene and ITS region confirmed the species identification obtained by SADH-RFLP (Table 1). Sequence analysis of the $26 \mathrm{~S}$ rRNA (D1/D2) region failed to differentiate C. parapsilosis from C. metapsilosis and $C$. orthopsilosis, even for the C. orthopsilosis and C. metapsilosis ATCC reference strains (Table 1).

To evaluate the nucleotide variation, the sequences obtained in this study were also subjected to multiple alignment and analysis of phylogenetic trees, separately for each region and also concatenated for all regions. A total of $592 \mathrm{nt}$ for the SADH gene, $434 \mathrm{nt}$ for the ITS1-ITS2 region, $591 \mathrm{nt}$ for $26 \mathrm{~S}$ rRNA (data not shown) and $1617 \mathrm{nt}$ for the concatenated analysis were used. As shown in Fig. 2, two of four clinical isolates that initially were identified as C. orthopsilosis by SADH PCR-RFLP, grouped with C. metapsilosis ATCC 96144. The $S A D H$ sequence was identical when compared to the two Danish C. metapsilosis isolates and did not contain a BanI cutting site. The ATCC 96144 C. metapsilosis SADH sequences were $95 \%$ similar to the two Danish isolates, and the reference strain contained a BanI cutting site.

With the objective of designing a better $S A D H$-RFLP profile for species separation and identification of the $C$. parapsilosis group, all available sequences of the $S A D H$ gene, including the sequences obtained from the present study and sequences previously deposited in GenBank, were analysed and restriction patterns were predicted for

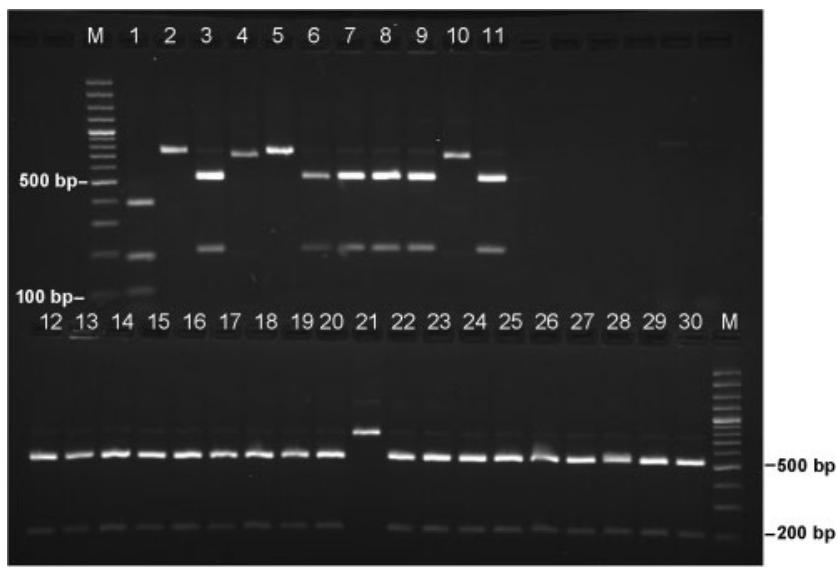

Fig. 1. Agarose gel electrophoresis of $S A D H$ PCR products digested by the restriction enzyme Banl. Lane 1, C. metapsilosis ATCC 96144; lane 2, C. orthopsilosis ATCC 96139; lane 3, C. parapsilosis ATCC 22019; lanes 4-30, blood culture isolates; lane $M, 100$ bp molecular size marker. Note the single band pattern in lanes 4, 5, 10 and 21, as well as for the reference strain C. orthopsilosis (lane 2). Note also the slightly smaller band size for samples 4 and 10 (which were eventually identified as $C$. metapsilosis). 
Table 1. Molecular identification of 79 clinical C. parapsilosis sensu lato blood culture isolates and 3 reference strains using phenotyping and a complement of molecular methods

\begin{tabular}{|c|c|c|c|c|c|}
\hline \multirow[t]{2}{*}{ Strain } & \multicolumn{5}{|c|}{ Species identification obtained by: } \\
\hline & $\begin{array}{c}\text { SADH PCR-RFLP } \\
\text { with BanI }\end{array}$ & $\begin{array}{l}\text { SADH gene } \\
\text { sequencing }\end{array}$ & $\begin{array}{l}\text { ITS1-ITS2 } \\
\text { sequencing }\end{array}$ & $\begin{array}{l}\text { 26S rRNA (D1/D2) gene } \\
\text { sequencing }\end{array}$ & $\begin{array}{c}\text { SADH PCR-RFLP } \\
\text { with NlaIII }\end{array}$ \\
\hline ATCC 22019 & C. parapsilosis & C. parapsilosis & C. parapsilosis & C. parapsilosis & C. parapsilosis \\
\hline ATCC 96144 & C. metapsilosis & C. metapsilosis & C. metapsilosis & $\begin{array}{l}\text { C. orthopsilosis/parapsilosis/ } \\
\text { metapsilosis }\end{array}$ & C. metapsilosis \\
\hline W36279 \& T19754 & C. orthopsilosis & C. metapsilosis & C. metapsilosis & $\begin{array}{l}\text { C. orthopsilosis/parapsilosis/ } \\
\text { metapsilosis }\end{array}$ & C. metapsilosis \\
\hline T27682 \& F10552 & C. orthopsilosis & C. orthopsilosis & C. orthopsilosis & $\begin{array}{l}\text { C. orthopsilosis/parapsilosis/ } \\
\text { metapsilosis }\end{array}$ & C. orthopsilosis \\
\hline $\begin{array}{l}\text { Remaining } 75 \text { blood } \\
\text { isolates }\end{array}$ & C. parapsilosis & Not done ${ }^{*}$ & Not done ${ }^{\star}$ & Not done ${ }^{*}$ & C. parapsilosis \\
\hline
\end{tabular}

${ }^{*}$ Three of these blood isolates underwent sequencing of the SADH gene and of the $26 \mathrm{~S}$ rRNA (D1/D2) gene region, and one blood isolate underwent ITS1-IRS2 sequencing, confirming the isolates to be C. parapsilosis.

610 (almost all available) restriction enzymes. The most applicable enzymes were MwoI, Hpy8I, MfeI, BstENII, AfaI, AlwI and NlaIII, but only NlaIII (FatI) and BstENII were predicted to have cutting sites for all three species. Comparing the predicted fragment sizes of NlaIII (FatI) and BstENII, NlaIII was superior, due to having the greatest difference in the main fragment sizes between the species. For NlaIII the following fragment sizes were found: C. parapsilosis - 131 and 505 bp, C. metapsilosis - 74, 288 and $348 \mathrm{bp}$, and C. orthopsilosis - 131, 217 and 288 bp. In comparison the following fragment sizes were found for BstENII: C. parapsilosis - 141 and 576 bp, C. metapsilosis - 158 and $559 \mathrm{bp}$, and C. orthopsilosis, 141, 158 and
$363 \mathrm{bp}$. The SADH PCR products of all blood culture isolates and reference strains were digested with NlaIII (examples are shown in Fig. 3). The fragment patterns were as expected and in agreement with the $S A D H$ gene sequence data. No additional $C$. orthopsilosis or $C$. metapsilosis isolates were found among clinical isolates by this new technique. Finally, susceptibility to amphotericin $\mathrm{B}$, caspofungin, fluconazole, itraconazole and voriconazole were compared. Given as MICs for the two C. metapsilosis isolates, MICs for the two C. orthopsilosis isolates and $\mathrm{MIC}_{50}$ (range) for the 75 C. parapsilosis isolates, the values $\left(\mu \mathrm{g} \mathrm{ml}^{-1}\right)$ were as follows: amphotericin $\mathrm{B}, 0.5$ and 0.25 , 0.5 and 0.5 , and $0.5(0.125-1)$, respectively; caspofungin,

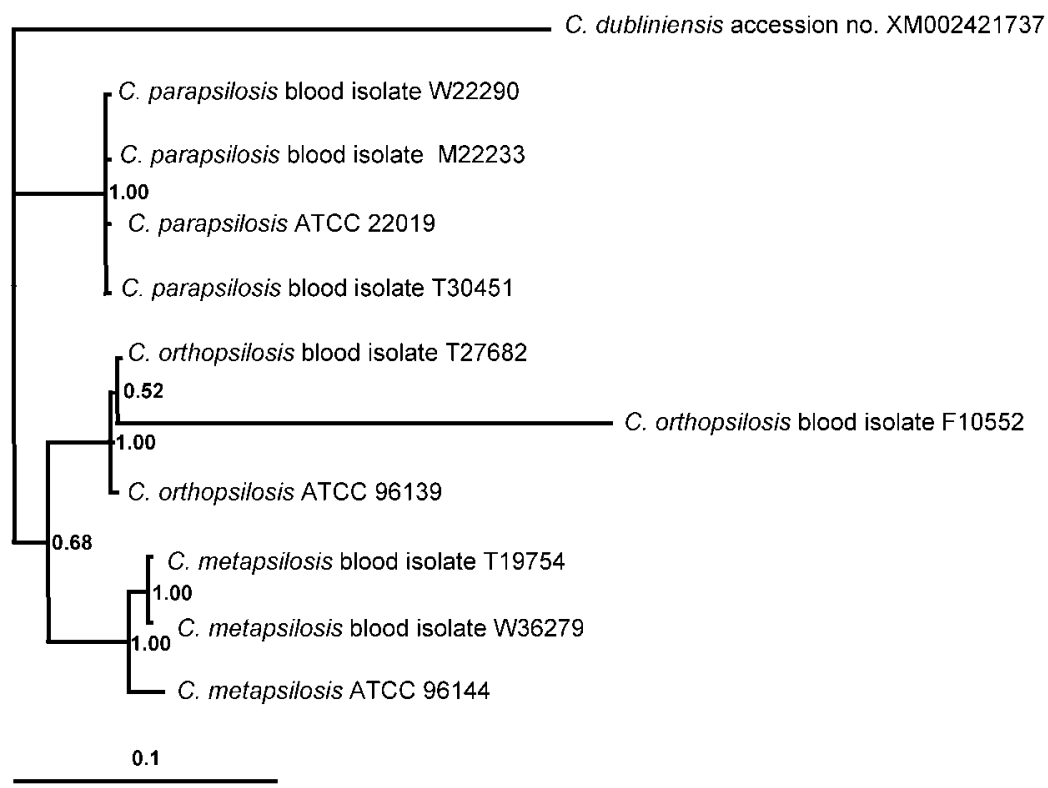

Fig. 2. Genetic relationships of C. parapsilosis sensu lato isolated from Danish patients with candidaemia and the three reference strains, C. parapsilosis ATCC 22019, C. orthopsilosis ATCC 96139 and C. metapsilosis ATCC 96144. C. dubliniensis was included as the outgroup. The relationships were inferred based on concatenated SADH, ITS and 26S rRNA gene sequence data. Nodal support is given as a posterior probability value. Bar, distance. 


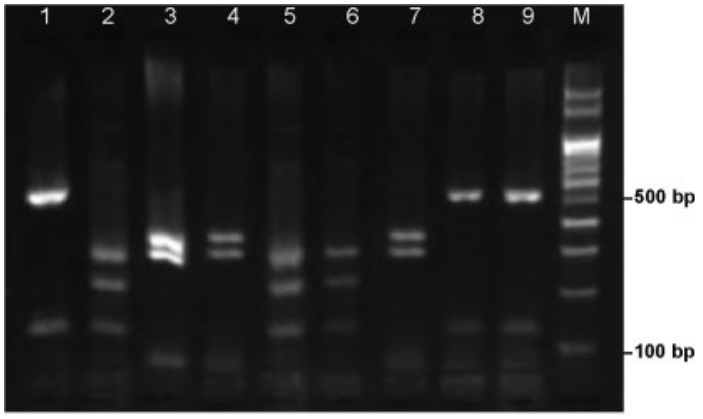

Fig. 3. Agarose gel electrophoresis of $S A D H$ PCR products of $C$. parapsilosis sensu lato after digestion with Nlalll. Lanes 1, 8 and 9 are C. parapsilosis ATCC 22019 and two clinical isolates of C. parapsilosis, respectively; lanes 2, 5 and 6 are C. orthopsilosis ATCC 96139 and the clinical isolates T27682 and F10552, respectively; lanes 3, 4 and 7 are C. metapsilosis ATCC 96144 reference strain and clinical isolates W36279 and T19754, respectively; lane $\mathrm{M}, 100$ bp molecular size marker.
0.5 and $1,0.5$ and 0.5 , and $2(0.5-4)$, respectively; fluconazole, 2 and $0.25,0.5$ and 1 , and 1 (0.5-8), respectively; itraconazole, 0.125 and $\leqslant 0.032, \leqslant 0.032$ and $0.125,0.064(\leqslant 0.032-0.125)$, respectively; and voriconazole, 0.064 and $\leqslant 0.032$, $\leqslant 0.032$ and 0.064 , and $\leqslant 0.032$ $(\leqslant 0.032-0.125)$, respectively. Thus, no significant differences were observed.

In this study we have reported the prevalence of the recently described species C. orthopsilosis and C. metapsilosis in a welldefined sample of blood culture isolates from Denmark and a new low cost PCR-RFLP method for the reliable separation of the C. parapsilosis group into the three species. Overall, $2.5 \%$ of the isolates phenotypically identified as C. parapsilosis were C. orthopsilosis and $2.5 \%$ were C. metapsilosis. Table 2 summarizes the frequencies of $C$. orthopsilosis and $C$. metapsilosis in other studies of $C$. parapsilosis sensu lato. In the majority of studies, including all those with more than 100 isolates, $88 \%$ or more of the isolates were confirmed to be $C$. parapsilosis in agreement with the current findings. In Portugal, Spain and Denmark similar proportions of $C$. orthopsilosis and C. metapsilosis isolates were detected

Table 2. Summary of published studies on identification methods with distribution of C. parapsilosis, C. orthopsilosis and C. metapsilosis

\begin{tabular}{|c|c|c|c|c|c|c|}
\hline \multirow{2}{*}{$\begin{array}{l}\text { Method used for } \\
\text { differentiation }\end{array}$} & \multirow[t]{2}{*}{ Source of specimens } & \multicolumn{3}{|c|}{ No. of isolates (\%) by species } & \multirow{2}{*}{$\begin{array}{l}\text { Country or } \\
\text { region }\end{array}$} & \multirow[t]{2}{*}{ Reference } \\
\hline & & $\begin{array}{c}\text { C. } \\
\text { parapsilosis }\end{array}$ & $\begin{array}{c}\text { C. } \\
\text { orthopsilosis }\end{array}$ & $\begin{array}{c}\text { C. } \\
\text { metapsilosis }\end{array}$ & & \\
\hline $\begin{array}{l}\text { MLST, RAPD-PCR, } \\
\text { SADH RFLP }\end{array}$ & Various clinical sources & $20(74.1 \%)$ & $7(25.9 \%)$ & 0 & $\begin{array}{l}\text { USA, Europe, } \\
\text { Africa, Asia }\end{array}$ & Tavanti et al. (2005) \\
\hline $\begin{array}{l}\text { Direct PCR-sequencing } \\
\text { of BacTec }\end{array}$ & $\begin{array}{l}\text { Blood and other clinical } \\
\text { sources }\end{array}$ & $8(88.9 \%)$ & $1(11.1 \%)$ & 0 & Australia & Pryce et al. (2006) \\
\hline $\begin{array}{l}\text { ITS sequencing, RAPD } \\
\text { PCR, phenotyping data }\end{array}$ & $\begin{array}{l}\text { Blood and other clinical } \\
\text { sources }\end{array}$ & $18(90 \%)$ & 0 & $2(10 \%)$ & Hungary & Kocsubé et al. (2007) \\
\hline SADH-RFLP, AFLP & Various clinical sources & $277(95.5 \%)$ & $13(4.5 \%)$ & NI & Italy & Tavanti et al. (2007) \\
\hline SADH-RFLP, AFLP & Various clinical sources & $375(94.9 \%)$ & NI & $20(5.1 \%)$ & Italy & Hensgens et al. (2009) \\
\hline ITS sequencing & Blood & $67(85.9 \%)$ & $5(6.4 \%)$ & $6(7.7 \%)$ & Spain & $\begin{array}{l}\text { Gomez-Lopez et al. } \\
\text { (2008) }\end{array}$ \\
\hline$S A D H$-RFLP & Invasive clinical samples & $1762(92.1 \%)$ & $117(6.1 \%)$ & $34(1.8 \%)$ & $\begin{array}{l}\text { Global study } \\
(89 \text { countries })\end{array}$ & Lockhart et al. (2008) \\
\hline $\begin{array}{l}\text { ITS-sequencing, RAPD } \\
\text { PCR }\end{array}$ & Blood & $29(70.7 \%)$ & $10(24.4 \%)$ & $2(4.9 \%)$ & Malaysia & Tay et al. (2009) \\
\hline $\begin{array}{l}\text { PCR with specific } \\
\text { primers, SADH-RFLP, } \\
\text { D1/D2 and ITS } \\
\text { sequencing }\end{array}$ & $\begin{array}{l}\text { Blood (66) and other } \\
\text { clinical sources }(48)\end{array}$ & $109(95.6 \%)$ & $5(4.4 \%)$ & 0 & Kuwait & $\begin{array}{l}\text { Asadzadeh et al. } \\
\text { (2009) }\end{array}$ \\
\hline SADH-RFLP & $\begin{array}{l}\text { Clinical and } \\
\text { environmental sources }\end{array}$ & $160(94.67 \%)$ & $4(2.37 \%)$ & $5(2.96 \%)$ & Portugal & Silva et al. (2009) \\
\hline ITS sequencing & Blood & $126(88.1 \%)$ & $13(9.1 \%)$ & $4(2.8 \%)$ & Brazil & $\begin{array}{l}\text { Gonçalves et al. } \\
\text { (2010) }\end{array}$ \\
\hline $\begin{array}{l}\text { SADH-RFLP, SADH, } \\
\text { ITS and } 26 \mathrm{~S} \\
\text { sequencing }\end{array}$ & Blood & $75(95 \%)$ & $2(2.5 \%)$ & $2(2.5 \%)$ & Denmark & Present study \\
\hline
\end{tabular}

NI, Not indicated. 
(Gomez-Lopez et al., 2008; Silva et al., 2009), while C. orthopsilosis was more frequent than C. metapsilosis in a worldwide study with almost 2000 isolates (Lockhart et al., 2008) and in two smaller studies from Malaysia and Kuwait (Tay et al., 2009; Asadzadeh et al., 2009). To what extent these observations reflect true differences compared to methoddependent effects remains to be elucidated. Some studies have used SADH-RFLP with BanI, which we found unreliable for identifying C. metapsilosis. Some studies have used PCR sequencing of the D1/D2 region of $26 \mathrm{~S}$ rRNA gene; however, by sequence analysis (Table 1) including the use of phylogenetic trees, we showed that this region is not a suitable target for separation of the species within the $C$. parapsilosis group. The $26 \mathrm{~S}$ rRNA gene sequence is generally a highly conserved region, particularly in yeasts (Iwen et al., 2002). Thus it is foreseeable that $26 \mathrm{~S}$ rRNA (D1/D2) gene sequence may not be an optimal marker for differentiating closely related species.

Since the description of C. orthopsilosis and C. metapsilosis in 2005 (Tavanti et al., 2005), several methods have been proposed to identify and differentiate these species from $C$. parapsilosis sensu stricto. Tavanti et al. (2005) proposed PCR amplification of the $S A D H$ gene followed by restriction digestion with BanI, and used amplification fragment length polymorphism (AFLP) for identification and genotyping of about 400 isolates previously classified as C. parapsilosis. AFLP was shown to identify C. orthopsilosis (Tavanti et al., 2007) and C. metapsilosis (Hensgens et al., 2009) to the species level, and to be an efficient genotyping tool as well, delineating intraspecific genetic relatedness. Campa et al. (2008) developed an oligonucleotide microarray based on the arrayed-primer extension technique to simultaneously identify pathogenic fungi. They designed probes complementary to the ITS1 and ITS2 region for identification of 24 species, including C. parapsilosis, C. orthopsilosis and C. metapsilosis. Based on the major DNA fragments of the RAPD analysis profiles, Tay et al. (2009) identified the isolates as types $\mathrm{P} 1$ to $\mathrm{P} 5$. Sequence analysis of the ITS region of the isolates identified RAPD type $\mathrm{P} 1$ as $C$. parapsilosis, $\mathrm{P} 2$ and $\mathrm{P} 3$ as C. orthopsilosis, and $\mathrm{P} 4$ as C. metapsilosis. van Asbeck et al. (2008) reported the correlation of RFLP genotyping with ITS sequence, RAPD and multilocus sequencing for the $C$. parapsilosis group. According to Borman et al. (2009) pyrosequencing analysis of 20 nucleotides of the ITS2 region rapidly and robustly distinguished the three species. Finally, Asadzadeh et al. (2009) introduced primers derived from unique sequences within the ITS1-5.8S rDNA-ITS2 region for the purpose of differentiating the three species. All these methods have the advantages of a sequencing-based approach, but are time consuming and labour intensive, and some are expensive.

In our hands the SADH PCR-RFLP with the enzyme BanI successfully separated $C$. parapsilosis sensu stricto from the two new species, but the band patterns of $C$. orthopsilosis and C. metapsilosis were so similar that misclassification of C. metapsilosis as C. orthopsilosis must be expected in a routine setting. As PCR-RFLP is an attractive method due to low cost, we carefully analysed the $S A D H$ region in the C. parapsilosis complex for differences that predicted individual RFLP patterns and confirmed that the use of SADH-PCR followed by digestion by NlaIII could be a more reliable method for differentiating the three species. Further studies using this method and a higher number of C. metapsilosis and C. orthopsilosis isolates are needed to confirm the robustness of the method.

\section{ACKNOWLEDGEMENTS}

The authors' thanks are given to all who have contributed to this study, especially the technicians Birgit Brandt and Lis Wassmann at Statens Serum Institute, Copenhagen, Denmark, and Nilufar Jalalizand at Tehran University of Medical Sciences, Tehran, Iran.

\section{REFERENCES}

AFST-EUCAST (2008). EUCAST definitive document EDef 7.1: method for the determination of broth dilution MICs of antifungal agents for fermentative yeasts. Clin Microbiol Infect 14, 398-405.

Arendrup, M. C., Fuursted, K., Gahrn-Hansen, B., Schønheyder, H. C., Knudsen, J. D., Jensen, I. M., Bruun, B., Christensen, J. J. \& Johansen, H. K. (2008). Semi-national surveillance of fungaemia in Denmark 2004-2006: increasing incidence of fungaemia and numbers of isolates with reduced azole susceptibility. Clin Microbiol Infect 14, 487-494.

Asadzadeh, M., Ahmad, S., Al-Sweih, N. \& Khan, Z. U. (2009). Rapid molecular differentiation and genotypic heterogeneity among Candida parapsilosis and Candida orthopsilosis strains isolated from clinical specimens in Kuwait. J Med Microbiol 58, 745-752.

Borman, A. M., Linton, C. J., Oliver, D., Palmer, M. D., Szekely, A., Odds, F. C. \& Johnson, E. M. (2009). Pyrosequencing analysis of 20 nucleotides of internal transcribed spacer 2 discriminates Candida parapsilosis, Candida metapsilosis, and Candida orthopsilosis. J Clin Microbiol 47, 2307-2310.

Campa, D., Tavanti, A., Gemignani, F., Mogavero, C. S., Bellini, I., Bottari, F., Barale, R., Landi, S. \& Senesi, S. (2008). DNA microarray based on arrayed-primer extension technique for identification of pathogenic fungi responsible for invasive and superficial mycoses. J Clin Microbiol 46, 909-915.

Enger, L., Joly, S., Pujol, C., Simonson, P., Pfaller, M. A. \& Soll, D. R. (2001). Cloning and characterization of a complex DNA fingerprinting probe for Candida parapsilosis. J Clin Microbiol 39, 658-669.

Fell, J. W. (1993). Rapid identification of yeast species using three primers in a polymerase chain reaction. Mol Mar Biol Biotechnol 2, 174-180.

Garcia-Effron, G., Katiyar, S. K., Park, S., Edlind, T. D. \& Perlin, D. S. (2008). A naturally occurring proline-to-alanine amino acid change in Fkslp in Candida parapsilosis, Candida orthopsilosis, and Candida metapsilosis accounts for reduced echinocandin susceptibility. Antimicrob Agents Chemother 52, 2305-2312.

Gomez-Lopez, A., Alastruey-Izquierdo, A., Rodriguez, D., Almirante, B., Pahissa, A., Rodriguez-Tudela, J. L., Cuenca-Estrella, M. \& the Barcelona Candidemia Project Study Group (2008). Prevalence and susceptibility profile of Candida metapsilosis and Candida orthopsilosis: results from population-based surveillance of candidemia in Spain. Antimicrob Agents Chemother 52, 1506-1509.

Gonçalves, S. S., Amorim, C. S., Nucci, M., Padovan, A. C. B., Briones, M. R. S., Melo, A. S. A. \& Colombo, A. L. (2010). Prevalence 
rates and antifungal susceptibility profiles of C. parapsilosis species complex: results from a nationwide surveillance of candidaemia in Brazil. Clin Microbiol Infect 16 (in press).

Hensgens, L. A., Tavanti, A., Mogavero, S., Ghelardi, E. \& Senesi, S. (2009). AFLP genotyping of Candida metapsilosis clinical isolates: evidence for recombination. Fungal Genet Biol 46, 750-758.

Iwen, P. C., Hinrichs, S. H. \& Rupp, M. E. (2002). Utilization of the internal transcribed spacer regions as molecular targets to detect and identify human fungal pathogens. Med Mycol 40, 87-109.

Kato, M., Ozeki, M., Kikuchi, A. \& Kanbe, T. (2001). Phylogenetic relationship and mode of evolution of yeast DNA topisomerase II gene in the pathogenic Candida species. Gene 272, 275-281.

Kocsubé, S., Tóth, M., Vágvölgyi, C., Dóczi, I., Pesti, M., Pócsi, I., Szabó, J. \& Varga, J. (2007). Occurrence and genetic variability of Candida parapsilosis sensu lato in Hungary. J Med Microbiol 56, 190195.

Krcmery, V. \& Barnes, A. J. (2002). Non-albicans Candida spp. causing fungaemia: pathogenicity and antifungal resistance. J Hosp Infect 50, 243-260.

Lehmann, P. F., Lin, D. M. \& Lasker, B. A. (1992). Genotypic identification and characterization of species and strains within the genus Candida by using random amplified polymorphic DNA. J Clin Microbiol 30, 3249-3254.

Lin, D., Wu, L. C., Rinaldi, M. G. \& Lehmann, P. F. (1995). Three distinct genotypes within Candida parapsilosis from clinical sources. J Clin Microbiol 33, 1815-1821.

Lockhart, S. R., Messer, S. A., Pfaller, M. A. \& Diekema, D. J. (2008). Geographic distribution and antifungal susceptibility of the newly described species Candida orthopsilosis and Candida metapsilosis in comparison to the closely related species Candida parapsilosis. J Clin Microbiol 46, 2659-2664.

Lott, T. J., Kuykendall, R. J., Welbel, S. F., Pramanik, A. \& Lasker, B. A. (1993). Genomic heterogeneity in the yeast Candida parapsilosis. Curr Genet 23, 463-467.

Mirhendi, H., Diba, K., Rezaei, A., Jalalizand, N., Hosseinpur, L. \& Khodadadi, H. (2007). Colony-PCR is a rapid and sensitive method for DNA amplification in yeasts. Iran J Public Health 36, 40-44.
Nosek, J., Tomaska, L., Rycovska, A. \& Fukuhara, H. (2002). Mitochondrial telomeres as molecular markers for identification of the opportunistic yeast pathogen Candida parapsilosis. J Clin Microbiol 40, 1283-1289.

Pryce, T. M., Palladino, S., Price, D. M., Gardam, D. J., Campbell, P. B., Christiansen, K. J. \& Murray, R. J. (2006). Rapid identification of fungal pathogens in BacT/ALERT, BACTEC, and BBL MGIT media using polymerase chain reaction and DNA sequencing of the internal transcribed spacer regions. Diagn Microbiol Infect Dis 54, 289-297.

Roy, B. \& Meyer, S. A. (1998). Confirmation of the distinct genotype groups within the form species Candida parapsilosis. J Clin Microbiol 36, 216-218.

Silva, A. P., Miranda, I. M., Lisboa, C., Pina-Vaz, C. \& Rodrigues, A. G. (2009). Prevalence, distribution and antifungal susceptibility profile of Candida parapsilosis, C. orthopsilosis and C. metapsilosis in a tertiary care hospital. J Clin Microbiol 47, 2392-2397.

Tavanti, A., Davidson, A. D., Gow, N. A., Maiden, M. C. \& Odds, F. C. (2005). Candida orthopsilosis and Candida metapsilosis spp. nov. to replace Candida parapsilosis groups II and III. J Clin Microbiol 43, 284-292.

Tavanti, A., Hensgens, L. A. M., Ghelardi, E., Campo, M. \& Senesi, S. (2007). Genotyping of Candida orthopsilosis clinical isolates by amplification fragment length polymorphism reveals genetic diversity among independent isolates and strain maintenance within patients. J Clin Microbiol 45, 1455-1462.

Tay, S. T., Na, S. L. \& Chong, J. (2009). Molecular differentiation and antifungal susceptibilities of Candida parapsilosis isolated from patients with bloodstream infections. J Med Microbiol 58, 185-191.

van Asbeck, E., Clemons, K. V., Martinez, M., Tong, A. J. \& Stevens, D. A. (2008). Significant differences in drug susceptibility among species in the Candida parapsilosis group. Diagn Microbiol Infect Dis 62, 106-109.

White, T. J., Bruns, T. D., Lee, S. B. \& Taylor, J. W. (1990). Amplification and direct sequencing of fungal ribosomal RNA genes for phylogenetics. In PCR Protocols: a Guide to Methods and Applications, pp. 315-322. Edited by M. A. Innis, D. H. Gelfand, J. J. Sninsky \& T. J. White. San Diego, CA: Academic Press. 